\title{
BARREL TEMPERATURE EFFECTS ON THE MECHANICAL PROPERTIES OF INJECTION MOULDED PLASTIC PRODUCTS
}

\author{
J.0. Osarenmwinda ${ }^{1, *}$ and D. D Olodu ${ }^{2}$ \\ 1,2 DePARTMENT OF PRoduction ENGINEERING, UNIVERSITY OF BENIN, BENIN City, NIGERIA \\ E-mail addresses: ${ }^{1}$ joosarenmwinda@hotmail.com, ${ }^{2}$ gennusdickson2013@yahoo.com
}

\begin{abstract}
The study of the effect of barrel temperatures on the tensile strength, proof stress, percentage elongation and flexural modulus of injected moulded plastic products of polyvinyl chloride (PVC), polypropylene (PP) and high density polyethylene (HDPE) have been carried out. An existing mould was used for the production of tension and deflection test specimen. Then a plunger type of injection machine was used to mould test specimens at various barrel temperatures ranging from $1600^{\circ} \mathrm{C}$ to $280^{\circ} \mathrm{C}$, keeping all other process variables constant. The tensile and deflection test carried out on the specimen, The results obtained showed that the maximum tensile strength for $P V C, P P$, and HDPE are $6.10 \mathrm{~N} / \mathrm{mm}^{2}, 21.67 \mathrm{~N} / \mathrm{mm}^{2}$, and $12.94 \mathrm{~N} / \mathrm{mm}^{2}$ at barrel temperature of $270^{\circ} \mathrm{C}, 270^{\circ} \mathrm{C}, 210^{\circ} \mathrm{C}$; Maximum proof stress was $3.44 \mathrm{~N} / \mathrm{mm}^{2}, 20.63 \mathrm{~N} / \mathrm{mm}^{2}$, and $13.65 \mathrm{~N} / \mathrm{mm}^{2}$ at barrel temperature of $240^{\circ} \mathrm{C}, 250^{\circ} \mathrm{C}$ and $160^{\circ} \mathrm{C}$; Maximum percentage elongation was $281 \%, 172 \%$, and $313 \%$ at barrel temperature of $2700^{\circ} \mathrm{C}, 270^{\circ} \mathrm{C}$, and $230^{\circ} \mathrm{C}$ and Maximum flexual modulus was $19.56 \times 10^{2} \mathrm{~N} / \mathrm{mm}^{2}, 29.03 \times 10^{2} \mathrm{~N} / \mathrm{mm}^{2}$ and $27.88 \times 10^{2} \mathrm{~N} / \mathrm{mm}^{2}$ at barrel temperatures of $240^{\circ} \mathrm{C}, 280^{\circ} \mathrm{C}$, and $160^{\circ} \mathrm{C}$ respectively.
\end{abstract}

Keywords. barrel temperature,plastic products, injection moulding machine, tensile strength, flexual strength

\section{INTRODUCTION}

The utilization of process control and process monitoring are rarely fully implemented for the production of injection moulded products. This may be due to a poor scientific understanding of the moulding process based on the complexities of the process containing multiple variables affecting the final part [1]. Injection moulding is a cost-effective way to produce complex, three dimensional shapes at high volumes [2]. In the plastics industry, injection moulding makes up approximately 32 wt. \% of all plastic processing methods, second only to extrusion 36 wt. \% [3]. Plastics are family of man - made non metallic organic materials which are currently being used in wide applications in the manufacture of industrial as well as consumer products. The deformable state achieved by plastics at elevated temperature before chemically setting allows them to be shaped to any intricate form [4].

Optimum barrel (melt) temperature is the key to successful moulding because one basic requirement on an automatic injection moulding process is that the moulded parts must be ejected automatically without the need for secondary finishing operations $[5,6]$. Shubbar [7] studied the optimum injection temperature used for the production of polyethylene crates. The results revealed that producing the crates at a temperature range of $\left(260-280{ }^{\circ} \mathrm{C}\right)$ gave the best rheological and mechanical result. Westerdale and Kazmer [8] investigated the effects of temperature, relative humidity and feedstock temperature on injection moulded part quality based on part weight, part dimensions and short term mechanical properties observed from tensile testing. The results indicated that environmental conditions influenced the moulded part quality to varying degrees and that the environmental conditions should be controlled for applications with tight tolerances.

Zhou and Mallick [9] examined the effects of melt temperature and hold pressure on the static tensile and fatigue behavior of an injection-moulded $40 \mathrm{wt} \%$ talc-filled polypropylene. For specimens in the flow direction, both yield strength and fatigue strength increased with increasing hold pressure, but they were relatively insensitive to melt temperature while for specimens normal to the flow direction, both yield 
strength and fatigue strength increased with increasing hold pressure and decreased with increasing melt temperature. Su et al [10] studied the effect of barrel (melt) temperature on the morphology, thermal behavior and the resultant mechanical properties of the injection moulded bars. They found that the mechanical properties, especially the tensile ductility and the impact strength, were greatly affected by the processing temperature. The samples obtained at low temperatures had the highest elongation at break and impact strength, while those moulded at high temperatures had the poorest toughness. Sahin and Yayla [11] studied the mechanical properties of polypropylene random copolymer with different processing parameters . Njoku and Obikwelu [12] investigated the swelling characteristics and tensile properties of natural fibre reinforced plastic in solvents while Edelugo [13] examined the effect of reinforcement combination on the mechanical strength of glass reinforced plastic under increased temperature conditions.

Injection moulding is a very complex process and its process variable like barrel (melt) temperature, injection pressure, the material flow rate, mould temperature and flow pattern usually interact between themselves and with the polymer properties to influence the solid properties of the moulded products.A quantitative analysis of the influence of these factors on the properties of a moulded part will be helpful in gaining better insight into the presently used processing methods and stimulate creative thinking on improved processing methods.The aim of this research therefore is to study the effects of barrel temperature, one of the process variables, on the mechanical properties of injection moulded plastic products of polyvinyl chloride (PVC), Polypropylene (PP) and High Density Polyethylene (HDPE).

\section{MATERIALS AND METHODS}

\subsection{Materials}

The plastic materials used for this study were Polyvinyl chloride (PVC), Polypropylene homopolymer (PP) and High density polyethylene (HDPE).

\subsection{Moulding of Plastic Specimens}

It is necessary to determine the amount of plastic melt required to fill the mould [14]. This amount of plastic melt must be displaced by the plunger in one single stroke. This is described as a shot [15]. Therefore, total volume of plastic required per shot was estimated as $9.588 \mathrm{~cm}^{3} /$ shot [16]. The estimated amount of material per shot required for PVC, PP and HDPE is shown in Table 1 [16]. The clamping force which is the force that holds the mould closed during the injection process so that the mould will not open was determined to be 12 tons [16].

Table 1: Amount of material per shot required for PVC, PP AND HDPE [16].

\begin{tabular}{lcc}
\hline Material & Density $\left(\mathrm{g} / \mathrm{cm}^{3}\right.$ & $\begin{array}{c}\text { Amount of material } \\
\text { (grams/shot) }\end{array}$ \\
\hline PVC & 1.34 & 12.86 \\
PP & 0.9 & 8.64 \\
HDPE & 0.924 & 8.83 \\
\hline
\end{tabular}

\subsection{The moulding process}

A single-stage plunger injection moulding machine (Fox and Offord, 35 tons single-stage plunger), was used to mould the specimens. This machine has a shot capacity of about $1.5 \mathrm{oz}$ and maximum clamping force of 35 tons. The mould was clamped on the platen and the heaters for the mould and barrel were switched on. The temperature control for the mould was set at $60^{\circ} \mathrm{C}$ and that of the barrel at $150^{\circ} \mathrm{C}$. The machine was left undisturbed for 30 minutes for the temperature to stabilize. The first part of moulding was performed with PVC. When the temperature became stable, the electric pump that circulated the cooling water was switched on and then the hopper was loaded with PVC. Starting with the barrel temperature of $150^{\circ} \mathrm{C}$, and increasing the temperature at steps of $10^{\circ} \mathrm{C}$, until $240^{\circ} \mathrm{C}$ when the plastic became molten, the cavities were completely filled using an injection pressure of $100 \mathrm{~kg} / \mathrm{cm}^{2}$. A clamping force of 12 tons was used and before moulding at any temperature, an interval of 180 seconds was allowed for the temperature to stabilize. At $240^{\circ} \mathrm{C}$, ten specimens were moulded at a curing time of about 10 seconds before the mould was opened. Moulding continued until at a temperature of $280^{\circ} \mathrm{C}$ when thermal degradation was noticed. The moulding process was repeated with PP which melted at $240^{\circ} \mathrm{C}$ and then with HDPE which melted at $150^{\circ} \mathrm{c}$. The range of barrel temperature at which specimen were moulded were recorded.

\subsection{The Tension Test of Specimens}

The testing machines used in the experiment was a Monsanto Tensometer (Type 'W' Serial No. 8991). The specimen was firmly gripped in the machine and a force exerted by turning the shaft at a constant rate. The material was stressed as it moved and the forceextension curve was automatically plotted. The tension test was first carried out with PVC specimens 
moulded at the various barrel temperatures. The tension test was repeated with PP and HDPE specimens. The tensile strength, proof stress (based on $0.1 \%$ permanent deformation) and $\%$ elongation was determined using (1) - (3) respectively.

$$
\begin{aligned}
\text { Tensile Strength } & =\frac{\text { Maximum load }}{\text { Original Cross Sectional Area }} \\
\text { Proof Stress } & =\frac{\text { force at yield }}{\text { Cross Sectional Area }} \\
\% \text { Elongation } & =\frac{\text { Extension }}{\text { Gauge Length }} \times 100
\end{aligned}
$$

\subsection{The deflection and flexural modulus test}

A length of $100 \mathrm{~mm}$ was marked out on the central portion of specimen and then it was clamped rigidly between the two retort stands. The dial gauge was clamped, using the third retort stand, above the specimen and its head was allowed to rest on the specimen at the mid-section. Using the thin wire, the $1 \mathrm{~kg}$ weight was hung at the mid-section of the specimen. The set-up was allowed to stay undisturbed for 180 seconds in order to stabilize. The amount of deflection was read from the dial gauge and recorded. Four specimens were tested at each barrel temperature and the average value of deflection was determined. The experiment was repeated in exactly the same manner for all the different plastics (PVC, PP and HDPE). The flexural modulus of the specimens at the various barrel temperatures was determined using (4):

$$
\text { Flexural Modulus }=\frac{P L^{3}}{48 y}
$$

where $\mathrm{y}$ is the deflection in $\mathrm{mm}, \mathrm{p}$ is Load and $\mathrm{L}$ is Overall length

\section{RESULTS AND DISCUSSION}

The graphs showing the effect of temperature on tensile strength, proof stress, $\%$ elongation, deflection and flexural strength are shown in Figures 1 through 5 respectively.

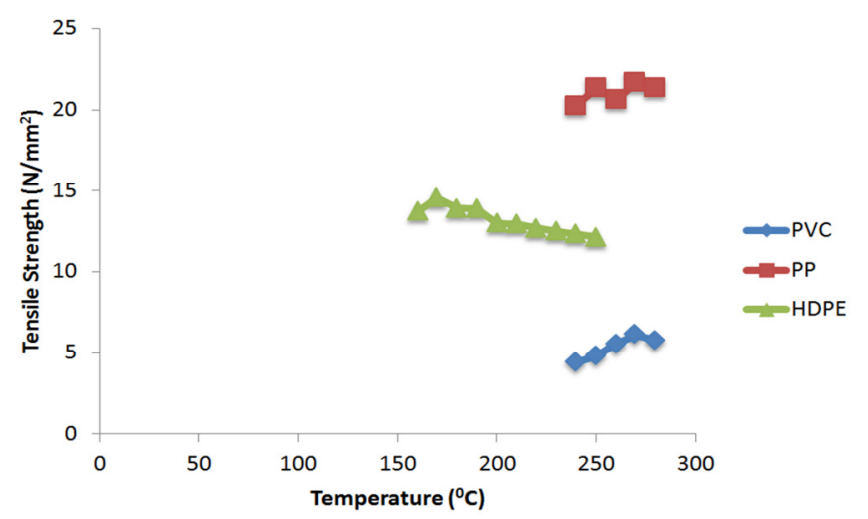

Figure 1: Effects of Barrel Temperature on Tensile

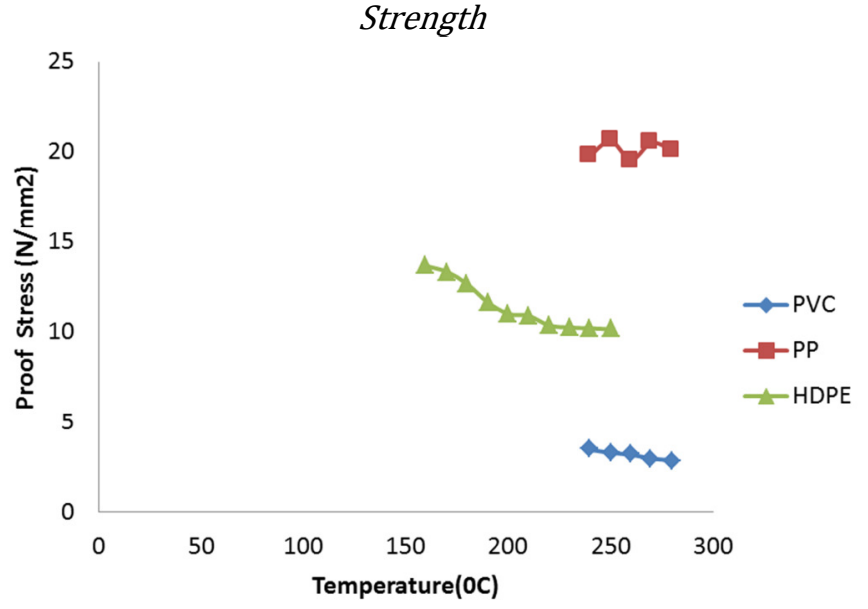

Figure 2: Effects of barrel temperature on proof stress

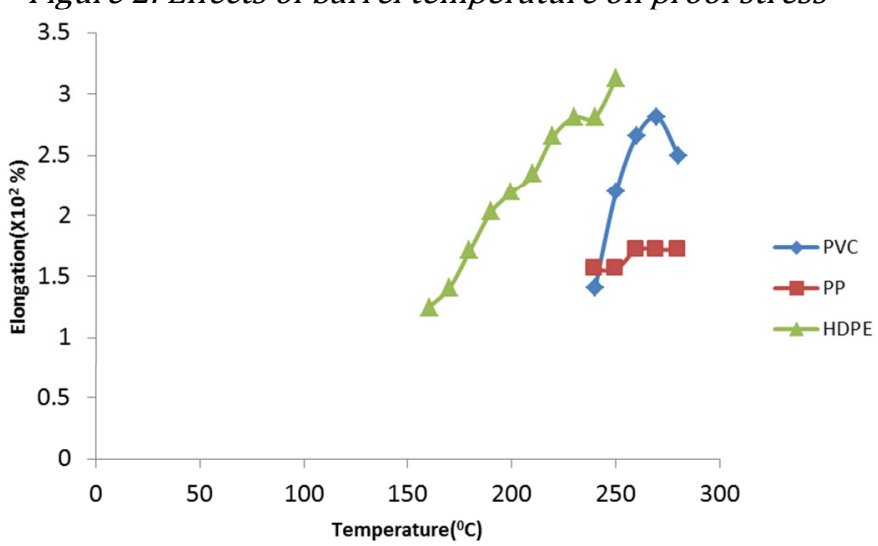

Figure 3: Effects of barrel temperature on percentage elongation.

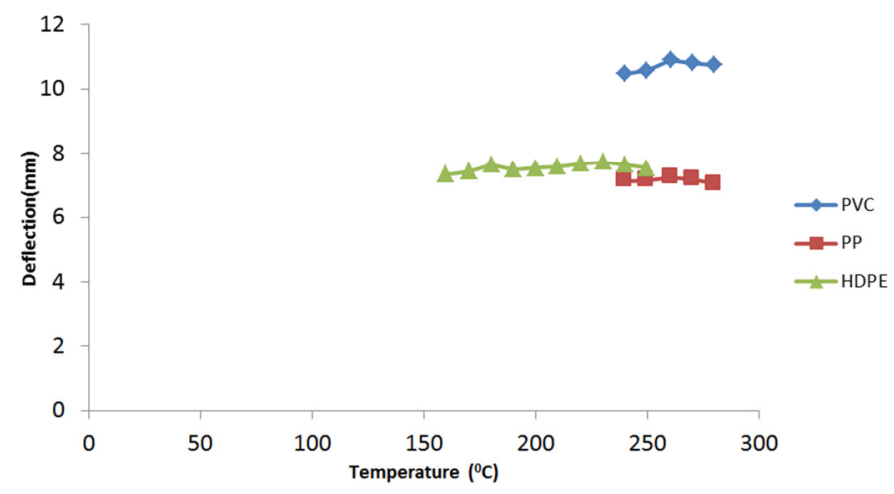

Figure 4: Effects of Barrel Temperature on Deflection 


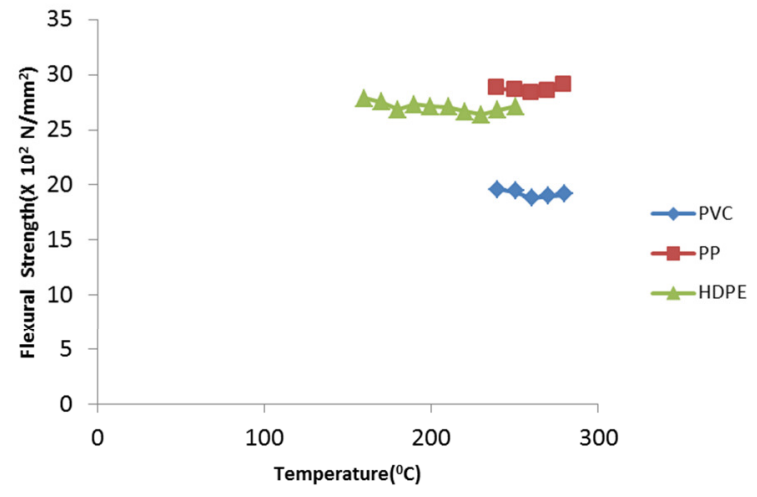

Figure 5: Effects of Barrel Temperature on Flexural Strength

\subsection{Effects of barrel temperature on tensile strength}

The tensile strength increased as the barrel temperature increased until a maximum tensile strength of $6.10 \mathrm{~N} / \mathrm{mm}^{2}, \quad 21.67 \mathrm{~N} / \mathrm{mm}^{2}$, and $12.94 \mathrm{~N} / \mathrm{mm}^{2}$ were attained for PVC, PP and HDPE are at barrel temperature of $270^{\circ} \mathrm{C}, 270^{\circ} \mathrm{C}, 210^{\circ} \mathrm{C}$ respectively (Fig. 1) after which the tensile strength began to decrease to a value of $5.82 \mathrm{~N} / \mathrm{mm}^{2}, 21.67$ $\mathrm{N} / \mathrm{mm}^{2}$ and $12.13 \mathrm{~N} / \mathrm{mm}^{2}$ at barrel temperature of $280^{\circ} \mathrm{C}, 270^{\circ} \mathrm{C}, 250^{\circ} \mathrm{C}$ respectively. This may be due to chain scissioning (molecular breakdown), reduction in molecular weight and melt viscosity hence decrease in crystallization and orientation occurring with processing temperatures above $280^{\circ} \mathrm{C}, 270^{\circ} \mathrm{C}, 250^{\circ} \mathrm{C}$ for PVC, PP and HDPE respectively $[7,10]$. These maximum values was found to compare favourably with a maximum value of $29.6 \mathrm{~N} / \mathrm{mm}^{2}$ at a barrel temperature of $260^{\circ} \mathrm{C}$ obtained by Sabuar [7] for High Density Polyethyene Crates.

\subsection{Effects of barrel temperature on proof Stress}

The Maximum proof stress for PVC, PP, HDPE was $3.44 \mathrm{~N} / \mathrm{mm}^{2}, 20.63 \mathrm{~N} / \mathrm{mm}^{2}$ and $13.65 \mathrm{~N} / \mathrm{mm}^{2}$ at barrel temperature of $240^{\circ} \mathrm{C}, 250^{\circ} \mathrm{C}$ and $160^{\circ} \mathrm{C}$ respectively (Figure 2). These maximum values were found to compare favourably with a maximum value of 29.52 $\mathrm{N} / \mathrm{mm}^{2}$ at a barrel temperature of $232^{\circ} \mathrm{C}$ obtained by Zhou and Mallick [9] and 25N/mm ${ }^{2}$ by Sahin and Yayla [11] for Talc-filled polyproylene and polypropylene random copolymer respectively. The proof stress for all the plastic material experienced a steady decrease after attaining these maximum values as the barrel temperature increased. This may be due to the fact that increase in the barrel temperature increases crystallinity and lowers viscosity, shear stress and orientation. This also permits greater relaxation ultimately leading to decrease in the proof stress and tensile strength of the moulded plastic product.

\subsection{Effect of Barrel Temperature On Percentage Elongation}

It was observed that the percentage elongation increased as the barrel temperature increased until a maximum percentage elongation of $281 \%, 172 \%$, and $313 \%$ were attained for PVC, PP and HDPE are at barrel temperature of $270^{\circ} \mathrm{C}, 270^{\circ} \mathrm{C}$, and $250^{\circ} \mathrm{C}$ respectively (Fig.3) after which the elongation began to decrease. The sudden fall in percentage elongation is due to molecular breakdown as thermal degradation began to set in above $270^{\circ} \mathrm{C}$. These values was found to compare favourably with a maximum value of $815 \%$ at a barrel temperature of $280^{\circ} \mathrm{C}$ obtained by Sabuar [7] for High Density Polyethyene Crates.

\subsection{Effect of barrel temperature on flexural modulus}

Maximum flexual modulus for PVC, PP, and HDPE are $19.56 \times 10^{2} \mathrm{~N} / \mathrm{mm}^{2}, 29.03 \times 10^{2} \mathrm{~N} / \mathrm{mm}^{2}$ and $27.88 \times 10^{2}$ $\mathrm{N} / \mathrm{mm}^{2}$ at barrel temperatures of $240^{\circ} \mathrm{C}, 280^{\circ} \mathrm{C}$, and $160^{\circ} \mathrm{C}$ respectively (Figure 5). This is slightly lower than the maximum value of $32.25 \times 10^{2} \mathrm{~N} / \mathrm{mm}^{2}$ obtained by Ranjusha et al [17] at temperature of $190^{\circ} \mathrm{C}$ for Polypropylene/High Density Polyethylene/Clay/Glass Fibre Composites probably due to the presence of clay and glass fibre in the Polypropylene material.

\section{CONCLUSION}

The study of the effect of barrel temperatures on the tensile strength, proof stress, percentage elongation and flexural strength of injected moulded plastic products of polyvinyl chloride (PVC), polypropylene (PP) and high density polyethylene (HDPE) have been investigated. The study showed that the barrel temperature has significant effect on the mechanical properties of the moulded plastic material. The maximum tensile strength for PVC, PP, and HDPE are $6.10 \mathrm{~N} / \mathrm{mm}^{2}, 21.67 \mathrm{~N} / \mathrm{mm}^{2}$, and $12.94 \mathrm{~N} / \mathrm{mm}^{2}$ at barrel temperature of $270^{\circ} \mathrm{C}, 270^{\circ} \mathrm{C}, 210^{\circ} \mathrm{C}$; Maximum proof stress was $3.44 \mathrm{~N} / \mathrm{mm}^{2}, \quad 20.63 \mathrm{~N} / \mathrm{mm}^{2}$, and $13.65 \mathrm{~N} / \mathrm{mm}^{2}$ at barrel temperature of $240^{\circ} \mathrm{C}, 250^{\circ} \mathrm{C}$ and $160^{\circ} \mathrm{C}$; Maximum percentage elongation was $281 \%, 172 \%$, and $313 \%$ at barrel temperature of $270^{\circ} \mathrm{C}, 270^{\circ} \mathrm{C}$, and $230^{\circ} \mathrm{C}$ and Maximum flexual modulus was $19.56 \times 10^{2} \mathrm{~N} / \mathrm{mm}^{2}, 29.03 \times 10^{2} \mathrm{~N} / \mathrm{mm}^{2}$ and $27.88 \times 10^{2} \mathrm{~N} / \mathrm{mm}^{2}$ at barrel temperatures of $240^{\circ} \mathrm{C}, 280^{\circ} \mathrm{C}$, and $160^{\circ} \mathrm{C}$ respectively. The knowlege obtained from these study will greatly assist material engineers and plastic manufacturers to have better 
understanding of plastics processing methods and enhance their productivity and efficiency .

\section{REFERENCES}

[1] Orzechowski, O., Paris A. and Dobbin, C. J. B. "A Process Monitoring and Control System for Injection Molding using Nozzle-based Pressure and Temperature Sensors", Annual Technical Conference - ANTEC, Conference Proceedings, 1998.

[2] Pasquini, N. Ed.. Polypropylene Handbook. Munich, Hanser, 2005.

[3] Rosato, D.V. Injection Molding Handbook, Springer Verlag, 2000.

[4] Pantani, R., Santis, F. D., Brucato, V. and .Timomanlio, G "Analysis of Gate Freeze-off time in injection moulding". Polymer Engineering and Science, 2004.

[5] Cermak, R. And Obadal, M. "Injection-molded [alpha] - and [beta]-polypropylenes: II. Tensile properties vs. processing parameters." European Polymer Journal Vol.42 No.9, 2006,: pp.2185-2191.

[6] Vorgelegt, V. "Design, Analysis and Simulation in Injection in-Mold Labeling" PHD Thesis, Thailand University of Stuttgart, 2009.

[7] Shubbar, S. D "Injection Temperature Effects on the Properties of High Density Polyethylene Crates" Journal of Engineering. Vol.19 No. 6, 2013, pp 754763.

[8] Westerdale, S. And Kazmer, D. "The effects of temperature and relative humidity on injection molded part quality", Society of Plastics Engineers Annual Technical Conference, 2008, pp 1-5.

[9] Zhou, Y. and Mallick, P.K. " Effects of Melt Temperature and Hold Pressure on the Tensile and Fatigue Properties of an Injection Molded TalcFilled Polypropylene" Polym. Eng. Sci.,Vol. 45, 2005, pp755-763.
[10] Su, R., Wang, K., Zhang, Q., Chen, F. and Fu, Q. "Effect of melt temperature on the phase morphology, thermal behavior and mechanical properties of injection-molded PP/LLDPE blends", Chinese Journal of Polymer Science, Vol.28, No. 2,2010 , pp 249-255.

[11] Sahin, S. and Yayla, P. "Effects of processing parameters on the mechanical properties of

polypropylene random copolymer." Polymer Testing Vol. 24,2005, pp 1012-1021.

[12] Njoku, R..E. and Obikwelu, D.O.."Swelling characteristics and tensile properties of natural fibre reinforced plastic in solvents",.Nigerian Journal of Technology, Vol.27,No. 2, 2008, pp 58-63.

[13] Edelugo, S.O. "Effect of reinforcements combination on the mechanical strength of glass reinforced plastic (GRP) handlay-up laminates under increased temperature conditions", .Nigerian Journal of Technology, Vol.23,No. 1, 2004, pp 3947.

[14] Irvin, R.I. Injection Moulding theory and practice. New York: John Wiley and sons, 2007.

[15] William, J.P. plastic technology, modern plastics technology, Reston Publishing Co. Inc. Prentice- Hall company, Reston, Virginia, 2006.

[16] Olodu, D.D "Barrel Temperature effects on the Mechanical Properties of Injection Moulded Plastic Products",.M.Eng Thesis, Department of Production Engineering, University of Benin, Benin City, Nigeria, 2012

[17] Ranjusha, J. P., Anjana, R. and George K.E. "Effect Of Moulding Temperature On The Properties of Polypropylene/ High Density Polyethylene/ Clay/ Glass Fibre Composites", International Journal of Engineering Research and Applications, Vol.2, No.5, 2012, pp.1922-1926. 